\title{
A Review on Nano Materials in Concrete
}

\author{
LV Prasad M* \\ Department of Civil Engineering, NIT Silchar-10, India \\ Submission: May 26, 2017; Published: September 20, 2017 \\ *Corresponding author: LV Prasad M, Department of Civil Engineering, NIT Silchar, India, Email: prasadsmlv@gmial.com
}

Abstract

The study of the application of nanotechnology in the construction industry and building structures is one of the most prominent priorities of the research community. The outstanding chemical and physical properties of nano materials enable several applications ranging from structural reinforcement to environmental pollution remediation and production of self-cleaning materials. It is known that concrete is the leading material in structural applications, where stiffness, strength and cost play a key role in the high attributes of concrete.

Keywords: Nano-scale; Nanotechnology; Nano-portland; Cement; Nano-cement particles; Cement mortar

Abbreviations: AFM: Atomic Force Microscopy; SEM: Scanning Electron Microscopy; FIB: Focused Ion Beam

\section{Introduction}

\section{Nanotechnology and concrete - general aspects}

Nanotechnology is a research area that has revolutionized mechanical and chemical properties of materials. Recently, focusing on concrete as a porous material with micro-scale and nano-scale pores, researchers developed investigations to find microstructure and mechanical and durability properties of concrete made with new materials. Although this is the most used definition, a size limitation of nanotechnology to a below $100 \mathrm{~nm}$ range seems to exclude numerous materials and devices, particularly in the pharmaceutical area. For that reason, some experts disagree with a rigid definition based on a sub $100 \mathrm{~nm}$ size $[1,2]$.

\section{Review of status of Research and Development}

During recent years, nano technology is developing with an ascending rate. Due to the new uses of nano particles there is an interest in the investigation of the effect of nano-particles; especially in concrete and cement mortar. Many of the available studies have focused on the effect of Nano-materials on the properties of hardened cement paste, cement mortar and/ or concrete. Portland cement is typically used as cementing materials with fine and coarse aggregates to create products that are a few mm to several meters thick. Average size of Portland cement particle is about 50 microns.

In applications that require thinner final products and faster setting time, micro cement with a maximum particle size of about 5 microns is being used $[3,4]$. Therefore the particle size has to be reduced by an order of magnitude to obtain nano-portland cement. If these nano-cement particles can be processed with nanotubes and reactive nano-size silica particles; conductive, strong, tough and room temperature processed ceramics can be developed both for electronic applications and coatings.

\section{Importance of the nano materials in concrete}

The role of nanotechnology in conceiving of innovative infrastructure systems has potential to revolutionize the civil engineering practice. Nanotechnology is the creation and utilization of functional materials, devices, and systems with novel properties and functions that are achieved through the control of matter, atom-by-atom, molecule-by-molecule, or at the nanoscale or macromolecular level. Addition of nano-scale materials into cement could improve its performance. The main advance is that we can learn about basic phenomena in cement at nano-scale. The better understanding of the structure and behavior of concrete at micro/nano-scale could help to improve concrete properties.

\section{Applications of nanotechnology in civil engineering}

Concrete the most ubiquitous material in the world, is a nanostructure, multi-phase, composite material that ages over time. It is composed of an amorphous phase, nanometer to micrometer size crystals and bound water. The properties of concrete exist in, and the degradation mechanisms occur across, multiple length scales (nano to micro to macro) where the properties of each scale derive from those of the next smaller scale [5]. 


\section{Nano Technology and Concrete}

Concrete is, a macro-material strongly influenced by its nanoproperties and understanding it at this new level is yielding new avenues for improvement of strength, durability and monitoring. Much of the analysis of concrete is being done at the nanolevel in order to understand its structure using the various techniques developed for study at that scale such as Atomic Force Microscopy (AFM), Scanning Electron Microscopy (SEM) and Focused Ion Beam (FIB). In fact, even some of the rules in structural concrete design are actually empirically derived from observed behavior Nanotechnology, involving the study of the fundamental components of concrete can lead the way to a real understanding of concrete construction and service life based on a designed material with predetermined properties [6].

\section{Concluding Remarks}

Having presented some of the most relevant and recent research works that has been carried out on the application of nanotechnology in the construction industry, it is possible to conclude that the potential of concrete nanotechnology will certainly be the key to a new construction's paradigm. Concrete production is responsible for high levels of $\mathrm{CO} 2$ emissions amongst many others pollutants. In that sense, the application of nonmaterial's in the construction industry should be considered not only to improve the physical and mechanical material properties, but also for environmental protection and energy saving. Experimental techniques have been developed, which made the characterization of material properties easier and reliable.

\section{References}

1. Bartos PJM, de Miguel Y, Porro A (2006) $2^{\text {nd }}$ international symposium on nanotechnology for construction: NICOM 2. RILEM Publications SARL, Spain.

2. Mondal P, Shah SP, Marks L (2008) Nanoscale characterization of cementitious materials. ACI Mater J 105(2): 174-179.

3. Sanchez F, Sobolev K (2010) Nanotechnology in concrete - A review. Construction and Building Materials 24: 2060-2071.

4. J Silvestre, N Silvestre, J de Brito (2016) Review on concrete nanotechnology. European Journal of Environmental and Civil Engineering 20(4): 455-485.

5. Garboczi E J (2009) Concrete nanoscience and nanotechnology: Definitions and applications. Nanotecnhology in Construction 3 81-88.

6. Li H, Xiao H, Yuan J, Ou J (2004) Microstructure of cement mortar with nano-particles. Composites Part B: Engineering 35: 185-189.

\section{Your next submission with Juniper Publishers will reach you the below assets}

- Quality Editorial service

- Swift Peer Review

- Reprints availability

- E-prints Service

- Manuscript Podcast for convenient understanding

- Global attainment for your research

- Manuscript accessibility in different formats

( Pdf, E-pub, Full Text, Audio)

- Unceasing customer service

Track the below URL for one-step submission https://juniperpublishers.com/online-submission.php 